\title{
Diversity of indigenous Bacillus thuringiensis isolates toxic to the diamondback moth, Plutella xylostella (L.) (Plutellidae: Lepidoptera)
}

\author{
R. Naga Sri Navya ${ }^{1}$ (1), V. Balasubramani ${ }^{2}$, M. Raveendran², M. Murugan ${ }^{1}$ and A. Lakshmanan ${ }^{3}$
}

\begin{abstract}
Background: Toxins from the Bacillus thuringiensis (Bt) bacterium are employed as an alternative to synthetic pesticides in pest management. The greatest threat to the long-term viability of $B t$ toxins is resistance evolution in the target pests. Genetic diversity and toxicity of $B t$ isolates were studied in this work in order to find $B t$ isolates with novel cry genes.
\end{abstract}

Results: In terms of colony morphology, among a total of 60 isolates, 51 isolates had off-white colour colonies with typical fried egg appearance, irregular shape, flat and undulate margin. Different crystal shapes, viz. spherical (88.13\%), bipyramidal (49.15\%), cuboidal (42.37\%), rectangular, and crystals attached to spores (3.38\%) were observed among Bt isolates. SDS-PAGE analysis of spore crystal mixture showed the presence of proteins with various molecular weights ranging from 124 to $26 \mathrm{kDa}$. PCR screening with cry 1, cry2, cry9 and vip3A1 primers showed isolates with varied insecticidal gene combinations. Bt isolates containing cryl genes were found to be abundant (30), followed by cry2 (9) and vip3A1 (9). Cry9 was absent in all the 60 isolates tested. Insecticidal activity of spore crystal mixtures ranged from 0 to $100 \%$ mortality. Furthermore, 12 isolates were found to be highly toxic against the larvae of diamondback moth, Plutella xylostella (L.) (Plutellidae: Lepidoptera) with 100\% mortality, at $25 \mathrm{\mu g} / \mathrm{ml}$ in leaf disc bioassay.

Conclusions: The present work established the diversity of $B t$ isolates and confirmed the importance of continuous exploration of new $B t$ isolates for novel genes. Further, research needs to be carried out to unveil the hidden potential of these toxic isolates.

Keywords: Bacillus thuringiensis, Diversity, Plutellaxylostella, Genes, Mortality, Crystal, Morphology toxicity, Toxins

\section{Background}

The most widely used biopesticide, Bacillus thuringiensis (Berliner) (Bacillaceae: Bacillales) (Bt), is a gram-positive, spore-forming entomopathogenic bacterium usually found in soil, leaf surfaces, grain dusts, dead insects and aquatic environments (Gupta et al. 2021). Bt can be distinguished from other Bacillus spp. due to its capacity to produce insecticidal proteins during sporulation

\footnotetext{
*Correspondence: balasubramani.v@gmail.com

${ }^{2}$ Department of Plant Biotechnology, Centre for Plant Molecular Biology and Biotechnology, Tamil Nadu Agricultural University,

Coimbatore 641003, India

Full list of author information is available at the end of the article
}

phase as parasporal inclusions, which predominantly comprises of Cry and Cyt toxins (Schnepf et al. 1998). Numerous $B t$ strains that showed toxic activity towards wide range of insects including Lepidoptera, Coleoptera, Diptera, Homoptera, Mallophaga, Hymenoptera and Nematodes (Sandeep et al. 2020) have been isolated and eventually used to develop biopesticides. At present, 400 $B t$-based formulations made up of insecticidal proteins and spores have been registered in the market. These toxins are employed in pest management in the form of foliar sprays or by delivering them to the target insect through the expression of toxin encoding genes in the transgenic plants (George and Crickmore 2012). Biopesticides are applied at $10-50 \mathrm{~g} /$ acre or $10^{20}$ molecules/ 
acre, while chemical pesticides such as organophosphates and pyrethroids are applied at $8 \times 10^{24}$ and $3 \times 10^{22} \mathrm{~mol}-$ ecules/acre, respectively. By this, the molecular potency of $B t$ toxins is 80,000 and 300 times higher than organophosphates and pyrethroids (Singh et al. 2021). Based on the amino acid sequence homology, 80 holotypes of crystal proteins (Cry1-Cry80), 4 holotypes of vegetative insecticidal proteins (Vip1-Vip4) and 7 holotypes of cytolytic proteins (Cyt1-Cyt7) of $B t$ have been identified (Crickmore et al. 2018). Cry proteins are highly selective to their target insect, innocuous to humans, non-target pests, vertebrates and rapidly degrade in the environment. Therefore, $B t$ is an effective alternative for the control of insect pests in agriculture. However, the primary disadvantage in the long-term use of $B t$ toxins contribute in decreasing susceptibility of pest population. It has been shown that insects developed resistance to $B t$ toxins in the laboratory and in field to $B t$ sprays (Jurat-Fuentes et al. 2021). As a result, isolation of $B t$ strains with novel toxins has gained significant importance for providing alternatives to these problems. With this background, the present study was carried out to screen novel $B t$ isolates that could be toxic to the diamondback moth, P. xylostella larvae under controlled conditions.

\section{Methods}

\section{Insect culture}

A laboratory culture of $P$. xylostella was established initially from pupae obtained from National Bureau of Agricultural Insect Resources, Bangalore, India. The pupae were transferred to the rearing cages $(45 \times 45 \times 45 \mathrm{~cm})$ for the emergence of adults. The newly emerged adults of P. xylostella were fed on $10 \%$ sugar solution, and mustard seedlings were provided as oviposition substrate and the hatched larvae were fed by fresh cauliflower leaves (CFL-1522, Syngenta) maintained under greenhouse conditions without any insecticide application. The larvae were placed in a $(30 \times 30 \times 30 \mathrm{~cm})$ larval rearing cage with a glass top, wooden bottom and mesh on all 4 sides. The insect culture was maintained at the Insect Bioassay laboratory (Department of Plant Biotechnology, TNAU, Coimbatore, India) under controlled conditions of temperature, humidity and photoperiod $\left(25 \pm 1{ }^{\circ} \mathrm{C}, 75 \pm 5 \%\right.$ RH and 16: $8 \mathrm{~h}$ (L: D).

\section{$B t$ isolates and growth conditions}

Sixty native $B t$ isolates were obtained from Department of Plant Biotechnology, Centre for Plant Molecular Biology and Biotechnology, TNAU, Coimbatore, India. The reference strain Bacillus thuringiensis subsp. Kurstaki HD1 originally obtained from Bacillus Genetic Stock Center (Columbus, Ohio) was used. In order to obtain single colonies, all the isolates were subcultured on T3 agar media plates using the quadrant streak method and incubated at $30{ }^{\circ} \mathrm{C}$ for $12-14 \mathrm{~h}$. Single colony was picked using sterile loop and transferred to the test tube containing $5 \mathrm{ml}$ of $\mathrm{T} 3 \mathrm{broth}$, incubated at $30{ }^{\circ} \mathrm{C}$ for $24 \mathrm{~h}$ at $200 \mathrm{rpm}$ and stored as sterile $50 \%$ glycerol stocks at $-20{ }^{\circ} \mathrm{C}$ for further use.

\section{Isolation of spore-crystal mixture for toxicity analysis}

The spore crystal mixture was isolated from $58 \mathrm{Bt}$ isolates and a reference strain, HD1 as a positive control and an acrystalliferous strain $78 / 11$ as a negative control. To obtain the spore crystal mixture from each isolate, a single colony of $B t$ culture from T3 agar plates was inoculated into culture tubes containing $5 \mathrm{ml}$ of T3 broth and kept for overnight incubation in a shaking incubator (Orbitek, Scigenics Biotech Pvt. Ltd, Chennai, India) maintained at $30{ }^{\circ} \mathrm{C}$ and $200 \mathrm{rpm}$. From the overnight grown cultures, $1 \%$ inoculum $(250 \mu \mathrm{l})$ was added to the $250-\mathrm{ml}$ conical flask containing $25 \mathrm{ml}$ of T3 broth in a shaking incubator maintained at $30{ }^{\circ} \mathrm{C}, 200 \mathrm{rpm}$ for $48-60 \mathrm{~h}$. The growth and lysis of the bacterial cells were checked using the phase contrast microscope after $48 \mathrm{~h}$. When more than $90 \%$ cells have lysed, culture was centrifuged at $4{ }^{\circ} \mathrm{C}$ for $10 \mathrm{~min}$ at 10,000 rpm (Centrifuge 5810R, Eppendorf, Germany) and resulting pellet was suspended in $25 \mathrm{ml}$ of ice-cold Tris-EDTA buffer [Tris $10 \mathrm{mM}$, EDTA $1 \mathrm{mM}, \mathrm{pH} 8.0$ with $1 \mathrm{mM}$ phenyl methyl sulphonyl fluoride (PMSF)] and washed once with $25 \mathrm{ml}$ of ice-cold $0.5 \mathrm{M} \mathrm{NaCl}$ and centrifuged for $10 \mathrm{~min}$, followed by 2 washes with $25 \mathrm{ml}$ Tris-EDTA buffer with $0.5 \mathrm{mM}$ PMSF at the same speed and time (Ramalakshmi and Udayasuriyan 2010). Finally, the pellet was suspended in $500 \mu \mathrm{l}$ of sterile distilled water containing $10 \mu \mathrm{l}$ of $1 \mathrm{mM}$ PMSF and stored at $-20^{\circ} \mathrm{C}$ as aliquots of $50 \mu \mathrm{l}$ for later use.

\section{Colony and crystal morphology}

Colony morphology pertaining to colour, surface and margin of each single bacterial colony was observed from the culture plate maintained at $30^{\circ} \mathrm{C}$ for $24 \mathrm{~h}$. To examine the shape of the parasporal crystalline inclusions using glass slides, culture smears were prepared on a glass slide, heat fixed and stained with Coomassie brilliant blue stain (0.133\% Coomassie Brilliant Blue G250 in 50\% acetic acid) for about one min. Smears were washed gently in running water, blot-dried and observed through the phase contrast microscope.

\section{Protein analysis}

Protein analysis using sodium dodecyl sulphate-polyacrylamide gel electrophoresis (SDS-PAGE) was done for spore crystal mixture from all the $B t$ samples. SDS-PAGE was performed by following the standard protocol (Laemmli 1970), using $10 \%$ separating gel and $4 \%$ stacking gel. 
The spore crystal mixtures were mixed by loading buffer (4x) containing $0.25 \mathrm{M}$ Tris $\mathrm{HCl} \mathrm{pH} \mathrm{6.8,} \mathrm{8 \%} \mathrm{SDS,} \mathrm{40 \%}$ glycerol, $0.5 \%$ bromophenol blue in the ratio $4: 1$, respectively. Then, samples were boiled for 2 min before loading into wells. The molecular mass of the proteins was estimated using pre-stained three-colour protein ladder (Puregene, Genetix Biotech Asia Pvt. Ltd.) covering a wide range molecular weight from 10 to $315 \mathrm{kDa}$.

\section{Detection of cry genes in $B t$ isolates}

Total genomic DNA was isolated from a single bacterial colony of all isolates according to method described by Sambrook and Russell (2001) and used as a template for the amplification of cry1, cry2, cry9 and vip $3 A 1$ genes. The isolated DNA was quantified through NanoDrop (Genova Nano, Jenway), and the integrity was evaluated by agarose gel electrophoresis (1\%). Each polymerase chain reaction (PCR) mixture contained 20-50 ng template DNA, $1 \mu \mathrm{M}$ of each primer (Ben-Dov et al. 1997) and $10 \mu \mathrm{l}$ of $2 \times$ PCR Master Mix (Smart prime) consisting of dNTPs, Taq polymerase and PCR buffer, and the final volume was made up to $20 \mu \mathrm{l}$ with sterile distilled water. PCR amplification was performed in a thermal cycler (ProFlex PCR system, Applied Biosystems). The PCR amplicons were separated in 1\% agarose gel using $1 \mathrm{~kb}$ DNA ladder. The amplified products were visualized under UV transilluminator (Bio-Rad).

\section{Insect toxicity assays with $B t$ isolates}

Insecticidal activity of the spore crystal mixtures of all the $B t$ isolates was tested against 3-day-old P. xylostella larvae. In order to conduct the bioassay, the protein concentration was estimated using Bradford method (Bradford 1976) and the suspension was diluted to $25 \mu \mathrm{g} / \mathrm{ml}$ of concentration in all the isolates before conducting toxicity tests. In all the cases, spore crystal mixture was smeared on small discs ( $25 \mathrm{~mm}$ diameter) of cauliflower leaves and allowed to dry. To prevent desiccation, all the leaf discs were placed on the wet surface of Whatman filter paper discs in plastic cups (30 mm diameter). For each isolate, 3 replications with 10 larvae per replicate were used. The standard strain, Bt subsp. kurstaki (Btk) HD1 and acrystalliferous strain 78/11 were used as positive and negative controls, respectively. Insect mortality was recorded at 24-h interval for 3 days, and cumulative mortality at $72 \mathrm{~h}$ was taken as mortality for comparing isolates.

\section{Statistical analysis}

Experiments were carried out in a completely randomized design (CRD). Single-dose bioassays were statistically analysed by one-way analysis of variance (ANOVA) using AGRES statistical software version 7.01, and significant differences between means were determined by Duncan's multiple range test $(p=0.05)$.

\section{Results}

Characterization based on colony and crystal morphology

$B t$ isolates were characterized based on colony colour, surface, shape, elevation, margin, cry gene content and protein profile. Among the 60 isolates, 53 isolates were off-white in colour, whereas 7 were full white. Colony surface was found to be fried egg type with flat elevation and undulate margin in 51 isolates, while smooth, raised and entire in 9 isolates. The colony shape of 53 isolates appeared as irregular whereas circular in 7 isolates (Table 1). Phase contrast microscopic (100x) observations (Iscope, Euromex) showed the presence of spores and crystal inclusions. Out of 51 isolates, crystal shape appearance was varied from spherical (88.13\%), bipyramidal (49.15\%), cuboidal (42.37\%), rectangular (3.38\%) and minute crystals attached to spores (3.38\%) (Table 2).

\section{Sodium dodecyl sulphate-polyacrylamide gel electrophoresis (SDS-PAGE)}

SDS-PAGE analysis of parasporal crystal proteins revealed various banding patterns among the $B t$ isolates. $B t$ isolates carried proteins of different molecular weights, viz. $\sim 124 \mathrm{kDa}$ (20 isolates), $\sim 90 \mathrm{kDa}$ (8 isolates), $\sim 70 \mathrm{kDa}$ (50 isolates), $\sim 60 \mathrm{kDa}$ (2 isolates), $\sim 55 \mathrm{kDa}(2$ isolates), $\sim 45 \mathrm{kDa}$ (11 isolates) and $\sim 26 \mathrm{kDa}$ (15 isolates) (Table 3).

\section{Distribution of lepidopteran specific cry and vip genes in Bt isolates}

PCR analysis for four lepidopteran specific genes (cry1, cry2, cry9 and vip3A1) showed the presence of only cry1, cry 2 and vip $3 A 1$ genes but not cry 9 gene. Out of 51 isolates, cry1, cry 2 and vip $3 A 1$ gene were found to be present in 30, 9 and 9 isolates, respectively. Fourteen isolates showed the presence of more than one gene, in different combinations (Table 3).

\section{Insecticidal activity against $P$. xylostella larvae}

From the toxicity results, it was evident that $12 \mathrm{Bt}$ isolates, viz. RM12, RM17, RM22, RM29, T15, T20, T29, T32, T152, T191, T380 and T405, showed 100\% mortality on par with the positive standard check, HD1 (Tables 4 \& 5) after $72 \mathrm{~h}$, against 3-day-old larvae of P. xylostella. Two isolates; RM14, T354 exhibited 90 and $93.33 \%$ mortality, respectively. $B t$ isolates RM3, RM27, RM28, VB7 and VB16 showed a very least toxicity $(<10 \%)$ against $P$. xylostella larvae. 
Table 1 Colony morphology of indigenous Bacillus thuringiensis isolates

\begin{tabular}{|c|c|}
\hline Colony parameters & Name of Bacillus thuringiensis isolates $(n=60)$ \\
\hline \multicolumn{2}{|l|}{ Colour } \\
\hline Full white (7) & RM1, RM5, RM7, RM8, RM13, RM28, RM1R1 \\
\hline Off-white (53) & $\begin{array}{l}\text { RM2, RM3, RM6, RM9, RM10, RM11, RM12, RM14, RM15, RM17, RM18, RM19, RM20, RM21, RM22, RM23, RM34, RM25, RM26, RM27, } \\
\text { RM29, RM30, RM1R2, T15, T16, T20, T29, T32, T152,T191, T210, T354, T380, T405, VB1, VB2, VB3, VB4, VB5, VB6, VB7, VB8, VB9, VB10, } \\
\text { VB11, VB12, VB16, VB17, VB18, VB19, VB20, HD1, 78/11 }\end{array}$ \\
\hline \multicolumn{2}{|r|}{ I } \\
\hline Fried egg (51) & $\begin{array}{l}\text { RM2, RM3, RM6, RM9, RM10, RM11, RM12, RM14, RM15, RM17, RM18, RM19, RM20, RM21, RM22, RM23, RM34, RM25, RM26, RM27, } \\
\text { RM29, RM30, RM1R2, T15, T16, T29, T32, T152, T191, T210, T354, T380, VB1, VB2, VB3, VB4, VB5, VB6, VB7, VB8, VB9, VB10, VB11, VB12, } \\
\text { VB16, VB17, VB18, VB19, VB20, HD1, 78/11 }\end{array}$ \\
\hline Smooth (9) & RM1, RM5, RM7, RM8, RM13, RM28, RM1R1,T20, T405 \\
\hline \multicolumn{2}{|l|}{ Shape } \\
\hline Irregular (53) & $\begin{array}{l}\text { RM2, RM3, RM6, RM9, RM10, RM11, RM12, RM14, RM15, RM17, RM18, RM19, RM20, RM21, RM22, RM23, RM34, RM25, RM26, RM27, } \\
\text { RM29, RM30, RM1R2, T15, T16, T20, T29, T32, T152, T191, T210,T354, T380, T405, VB1, VB2, VB3, VB4, VB5, VB6, VB7, VB8, VB9, VB10, } \\
\text { VB11, VB12, VB16, VB17, VB18, VB19, VB20, HD1, 78/11 }\end{array}$ \\
\hline Circular (7) & RM1, RM5, RM7, RM8, RM13, RM28, RM1R1 \\
\hline \multicolumn{2}{|l|}{ Elevation } \\
\hline Raised (9) & RM1, RM5, RM7, RM8, RM13, RM28, RM1R1,T20, T405 \\
\hline Flat (51) & $\begin{array}{l}\text { RM2, RM3, RM6, RM9, RM10, RM11, RM12, RM14, RM15, RM17, RM18, RM19, RM20, RM21, RM22, RM23, RM34, RM25, RM26, RM27, } \\
\text { RM29, RM30, RM1R2, T15, T16, T29, T32, T152, T191, T210, T354, T380, VB1, VB2, VB3, VB4, VB55, VB6, VB7, VB8, VB9, VB10, VB11, VB12, } \\
\text { VB16, VB17, VB18, VB19, VB20, HD1, 78/11 }\end{array}$ \\
\hline \multicolumn{2}{|r|}{ I } \\
\hline Entire (9) & RM1, RM5, RM7, RM8, RM13, RM28, RM1R1, T20, T405 \\
\hline Undulate (51) & $\begin{array}{l}\text { RM2, RM3, RM6, RM9, RM10, RM11, RM12, RM14, RM15, RM17, RM18, RM19, RM20, RM21, RM22, RM23, RM34, RM25, RM26, RM27, } \\
\text { RM29, RM30, RM1R2, T15, T16, T29, T32, T152, T191, T210, T354, T380, VB1, VB2, VB3, VB4, VB5, VB6, VB7, VB8, VB9, VB10, VB11, VB12, } \\
\text { VB16, VB17, VB18, VB19, VB20, HD1, 78/11 }\end{array}$ \\
\hline
\end{tabular}

${ }^{*}$ HD1 and 78/11 are standard strains

Table 2 Crystal morphology of Bacillus thuringiensis isolates

\begin{tabular}{lll}
\hline Crystal shape & $\begin{array}{l}\text { Number of isolates } \\
\text { (Total=59) }\end{array}$ & \% Occurrence \\
\hline Bipyramidal & 29 & 49.15 \\
Spherical & 52 & 88.13 \\
Cuboidal & 25 & 42.37 \\
Rectangular & 2 & 3.38 \\
Crystal attached to spore & 2 & 3.38 \\
\hline
\end{tabular}

\section{Discussion}

$B t$ collections exhibiting distinct level of toxicity to different insect pests are a good source of novel genes encoding for insecticidal proteins which could be employed in pest management. Bt isolates featured matt to granular surface textures with circular to irregular colonies and entire or undulate edges (Logan and De Vos 2011). Bt formed colonies on agar plates giving fried egg appearance as reported earlier (Zothansanga et al. 2016). The presence of parasporal crystalline inclusions is the common way to identify Bt (Rampersad and Ammons 2005). In the present study, spherical crystals were found in more frequency $(88.13 \%)$ than bipyramidal crystals
Table 3 Crystal protein profile and cry genes distribution in native $B$ t isolates

\begin{tabular}{|c|c|c|}
\hline Parameters & Variations observed & $\begin{array}{l}\text { No. of } \\
\text { isolates (out } \\
\text { of 59) }\end{array}$ \\
\hline \multirow[t]{7}{*}{ Protein size } & $\sim 124 \mathrm{kDa}$ & 20 \\
\hline & $\sim 90 \mathrm{kDa}$ & 8 \\
\hline & $\sim 70 \mathrm{kDa}$ & 50 \\
\hline & $\sim 60 \mathrm{kDa}$ & 2 \\
\hline & $\sim 55 \mathrm{kDa}$ & 2 \\
\hline & $\sim 45 \mathrm{kDa}$ & 11 \\
\hline & $\sim 26 \mathrm{kDa}$ & 15 \\
\hline \multirow{4}{*}{$\begin{array}{l}\text { Number of protein } \\
\text { bands in SDS-PAGE }\end{array}$} & One & 22 \\
\hline & Two & 25 \\
\hline & Three & 11 \\
\hline & Four & 1 \\
\hline \multirow{8}{*}{$\begin{array}{l}\text { Number of PCR-positive } \\
\text { isolates for cry genes }\end{array}$} & cry 1 & 30 \\
\hline & cry2 & 9 \\
\hline & cry9 & 0 \\
\hline & vip3 & 9 \\
\hline & $\operatorname{cry} 1+\operatorname{cry} 2$ & 10 \\
\hline & $\operatorname{cry} 1+\operatorname{cry} 2+v i p 3$ & 5 \\
\hline & cry $1+v i p 3$ & 9 \\
\hline & cry2 + vip3 & 5 \\
\hline
\end{tabular}


Table 4 Mortality of diamondback moth, Plutella xylostella caused by indigenous Bt isolates

\begin{tabular}{|c|c|c|c|c|c|c|c|}
\hline Treatments & Mortality (\%) & S. no & Treatments & Mortality (\%) & S. no & Treatments & Mortality (\%) \\
\hline RM1 & $36.7(37.3)^{\mathrm{hijklm}}$ & 21 & RM23 & $30.0(33.2)^{\mathrm{jklm}}$ & 41 & T405 & $100.0(90.0)^{a}$ \\
\hline RM2 & $50.0(45.0)^{\mathrm{fghi}}$ & 22 & RM24 & $43.3(41.2)^{g h i j k}$ & 42 & VB1 & $40.0(39.2)^{g^{g i j k l}}$ \\
\hline RM3 & $6.7(15.0)^{\mathrm{opq}}$ & 23 & $\mathrm{RM} 25$ & 43.3(41.2) ghijk & 43 & VB2 & $40.0(39.2)^{g h i j k l}$ \\
\hline RM5 & $66.7(54.7)^{\text {def }}$ & 24 & RM26 & $56.7(48.8)^{\mathrm{def}}$ & 44 & VB3 & $26.7(31.1)^{\mathrm{klmn}}$ \\
\hline RM6 & $70.0(56.8)^{\mathrm{cde}}$ & 25 & RM27 & $6.7(15.0)^{\mathrm{opq}}$ & 45 & VB4 & $56.7(48.8)^{\text {defg }}$ \\
\hline RM7 & $73.3(58.9)^{\mathrm{bcd}}$ & 26 & RM28 & $10.0(18.4)^{\text {nopq }}$ & 46 & VB5 & $46.7(43.1)^{g h i j}$ \\
\hline RM8 & $73.3(58.9)^{\mathrm{bcd}}$ & 27 & RM29 & $100.0(90.0)^{\mathrm{a}}$ & 47 & VB6 & $53.3(46.9)^{\text {efgh }}$ \\
\hline RM9 & $53.3(46.9)^{\mathrm{fgh}}$ & 28 & RM30 & $36.7(37.3)^{\mathrm{hijk} k \mathrm{~m}}$ & 48 & VB7 & $3.3(10.5)^{\mathrm{pq}}$ \\
\hline RM10 & $86.7(68.6)^{\mathrm{abc}}$ & 29 & RM1R1 & $43.3(41.2)^{g h i j k}$ & 49 & VB8 & $50.0(45.0)^{g h i}$ \\
\hline RM11 & $86.7(68.6)^{\mathrm{abc}}$ & 30 & RM1R2 & $43.3(41.2)^{g h i j k}$ & 50 & VB9 & $50.0(45.0)^{\text {fghik }}$ \\
\hline $\mathrm{RM} 12$ & $100.0(90.0)^{\mathrm{a}}$ & 31 & $\mathrm{~T} 15$ & $100.0(90.0)^{\mathrm{a}}$ & 51 & VB10 & $43.3(41.2)^{g h i j k}$ \\
\hline RM13 & $40.0(39.2)^{\text {ghjkl }}$ & 32 & $\mathrm{~T} 16$ & $26.7(31.1)^{\mathrm{k} / \mathrm{mn}}$ & 52 & VB11 & $33.3(35.3)^{\mathrm{j} / \mathrm{m}}$ \\
\hline RM14 & $90.0(71.6)^{\mathrm{ab}}$ & 33 & $\mathrm{~T} 20$ & $100.0(90.0)^{\mathrm{a}}$ & 53 & VB12 & $10.0(18.4)^{\text {nopq }}$ \\
\hline RM15 & $46.7(43.1)^{g h i j}$ & 34 & T29 & $100.0(90.0)^{\mathrm{a}}$ & 54 & VB16 & $0.0(0.5)^{q}$ \\
\hline RM17 & $100.0(90.0)^{\mathrm{a}}$ & 35 & T32 & $100.0(90.0)^{\mathrm{a}}$ & 55 & VB17 & $56.7(48.8)^{\text {defg }}$ \\
\hline RM18 & $53.7(47.1)^{\text {efgh }}$ & 36 & T152 & $100.0(90.0)^{\mathrm{a}}$ & 56 & VB18 & $23.3(28.9)^{\operatorname{lmno}}$ \\
\hline RM19 & $43.3(41.2)^{\text {ghijk }}$ & 37 & T191 & $100.0(90.0)^{\mathrm{a}}$ & 57 & VB19 & $20.0(26.6)^{\mathrm{mnop}}$ \\
\hline RM20 & $53.3(46.9)^{\mathrm{efh}}$ & 38 & $\mathrm{~T} 210$ & $30.0(33.2)^{j \mathrm{klm}}$ & 58 & VB20 & $20.0(26.6)^{\mathrm{mnop}}$ \\
\hline RM21 & $43.3(41.2)^{9 j \mathrm{jk}}$ & 39 & T354 & $96.7(79.5)^{\mathrm{a}}$ & 59 & HD1 & $100.0(90.0)^{\mathrm{a}}$ \\
\hline RM22 & $100.0(90.0)^{\mathrm{a}}$ & 40 & T380 & $100.0(90.0)^{\mathrm{a}}$ & 60 & Control & $0.0(0.5)^{\mathrm{q}}$ \\
\hline SEd & 0.8654 & & & & & & \\
\hline CD (0.05) & 1.7135 & & & & & & \\
\hline
\end{tabular}

Figures in parentheses are arcsine transformed values of percentages

Values followed by same letters in a column are not significantly different ( 0.05$)$ by DMRT

Table 5 Grouping of Bt isolates based on mortality of Plutella xylostella larvae at $25 \mu \mathrm{g} / \mathrm{ml}$

\begin{tabular}{ll}
\hline Bacillus thuringiensis isolates & $\begin{array}{l}\text { Mortality } \\
\text { range } \\
\text { (\%) }\end{array}$ \\
\hline $\begin{array}{l}\text { RM12, RM17, RM22, RM29, T15, T20, T29, T32, T152, T191, } \\
\text { T380, T405 }\end{array}$ & 100 \\
RM14, T354 & $90-99$ \\
RM7, RM8, RM10, RM11 & $70-89$ \\
RM5, RM6, RM20, RM26, VB4, VB6, VB8, VB9, VB17 & $50-69$ \\
RM1, RM2, RM9, RM13, RM19, RM21, RM23, RM24, RM25, & $30-49$ \\
RM30, RM1R1, RM1R2, T210, VB5, VB11 & \\
RM15, RM18, T16, VB1, VB2, VB3, VB10, VB12, VB18, VB19, VB20 & $10-29$ \\
RM3, RM27, RM28, VB7, VB16 & $0-9$ \\
\hline
\end{tabular}

(49.15\%). These findings are in accordance with reports by Reyaz et al. (2017) from India and Nair et al. (2018) from Qatar. Apart from these shapes, in the present study cuboidal crystals and crystals attached to spore were found in 42.37 and $3.38 \%$ isolates, respectively, as reported earlier by Rampersad and Ammons (2005). On the other hand, Ramalakshmi and Udayasuriyan (2010) observed more frequent occurrence of cuboidal (27\%) and bipyramidal crystals (21\%) among the $316 \mathrm{Bt}$ isolates tested. In terms of crystal morphology, isolates that are considered to be highly toxic produced 2 types of crystals, viz. bipyramidal and cuboidal, which is consistent with previous reports on crystal shape (Boonmee et al. 2019). All these variations in the morphology of crystalline inclusions suggested the presence of diversity in the studied isolates.

Carozzi et al. (1991) introduced PCR-based identification of cry genes to predict the insecticidal activity of $B t$ isolates, and it has since become a common tool. In the present study, cry 1 was more prevalent than $\operatorname{cry} 2$ and vip3A1 genes, in accordance with earlier reports (Lone et al. 2017). Among all the $B t$ isolates, only 16 showed the presence of single gene, while other positive isolates confirmed the presence of both cry and vip genes in combinations. Earlier, Ben-Dov et al. (1997) reported the tendency of occurrence of cry 1 and cry 2 genes together.

$B t$ isolates containing inter group crystalline protein encoding genes are ideal candidates for the development of broad-spectrum biopesticides. The findings presented here are similar to the previous reports (Sahin et al. 2018). All the 12 isolates that showed $100 \%$ mortality including positive control (HD1) were PCR-positive for cry1. These 
findings are comparable to those of Salama et al. (2015) who confirmed that, most isolates were PCR-positive for cry1 gene. In the present study, vip3A1-positive isolates have been identified to contain cry1 and cry2 genes also, in agreement with previous studies (Sahin et al. 2018).

SDS-PAGE analysis of all the $59 \mathrm{Bt}$ isolates revealed the existence of diversity in our collection. Among these, 22 isolates produced one protein band only while 25 isolates produced 2 separate protein bands with varying molecular weights. Out of $59 \mathrm{Bt}$ isolates, 50 produced proteins of $\sim 70 \mathrm{kDa}$, as reported earlier by Reyaz et al. (2017). The bands observed at $124 \mathrm{kDa}$ were next major proteins in the present study. Thirty $B t$ isolates produced protein bands in the range of 26 to $60 \mathrm{kDa}$. This wide range of protein banding pattern in these isolates suggested the variable biological activity and specificity for different insect pests. Ramalakshmi and Udayasuriyan (2010) found 2 protein bands of $\sim 135$ and $\sim 65 \mathrm{kDa}$ along with proteins of 95, 43 and $30 \mathrm{kDa}$ in their $B t$ isolates. Diverse electrophoretic patterns in Cry proteins with molecular weights ranging from 20 to $160 \mathrm{kDa}$ were reported earlier by Swamy et al. (2013).

Analysis of insecticidal activity of spore/crystal mixtures is an effective way to identify native $B t$ isolates with entomocidal properties (Sahin et al. 2018). In this study, 12 isolates were found to be highly toxic causing $100 \%$ mortality to $P$. xylostella larvae after 3 days. Kahrizeh et al. (2017) reported that 9 out of 148 isolates were highly toxic to P. xylostella larvae exhibiting 78.3 to $100 \%$ mortality. Monnerat et al. (2007) reported that 20 out of $1400 \mathrm{Bt}$ isolates were found to be $100 \%$ effective to 1 -dayold $2^{\text {nd }}$ instar $P$. xylostella larvae after 5 days in selective bioassays. Among a total of $104 \mathrm{Bt}$ isolates, 13isolates caused mortality that ranged between 30 and $100 \%$ against $P$. xylostella neonates (Silva et al. 2012).

\section{Conclusions}

The present work showed the diversity among the $B t$ isolates, in terms of protein content, colony and crystal morphology, cry gene content and toxicity to P. xylostella. The presence of more than one cry or vip gene in the isolates suggested that they had a high frequency of genetic information exchange. The existence of crystals in isolates that were not PCR-positive with the primer tested suggests that these isolates include cry/cyt genes that code for insecticidal proteins unique to other target insects from other lepidopteran families. The potency of toxic isolates in the present study (RM12, RM17, RM22, RM29, T15, T20, T29, T32, T152, T191, T380 and T405) to P. xylostella may be due to variations in amino acid sequences of cry or vip proteins, accumulation of cry toxins or a combination of these factors. Detailed studies on toxicity, spectrum of activity and speed of kill will help to decide the need for whole genome sequencing of the particular $B t$ isolate, isolation and cloning of novel cry genes. Such novel Cry proteins could be developed in to a biopesticide formulation for direct use in IPM or in development of newer transgenic crops.

\section{Abbreviations}

Bt: Bacillus thuringiensis; Cry: Crystal proteins; Cyt: Cytolytic proteins; Vip: Vegetative insecticidal proteins; dNTPs: Deoxyribo nucleotide triphosphates.

\section{Acknowledgements \\ Technical support received from the Department of Plant Biotechnol- ogy, Department of Agricultural Entomology and Department of Nano Science and Technology, Tamil Nadu Agricultural University, is gratefully acknowledged.}

\section{Authors' contributions}

VB designed the study. RNSN conducted the experiment. RNSN and VB wrote the manuscript. VB, MR and AL provided research material and helped in conducting the experiments. VB, MR, MM and AL helped in reviewing and editing the manuscript. All authors read and approved the final manuscript.

\section{Funding}

This work was funded by the Department of Science and Technology, Government of India, in the form of INSPIRE fellowship (IF180443) to R. Naga Sri Navya.

Availability of data and materials

Not applicable.

\section{Declarations}

Ethics approval and consent to participate Not applicable.

\section{Consent for publication}

All the authors give their consent to publish the submitted manuscript as "Original paper" in EJBPC.

\section{Competing interests}

The authors declare that they have no competing interests.

\section{Author details}

${ }^{1}$ Department of Agricultural Entomology, Tamil Nadu Agricultural University, Coimbatore 641003 , India. ${ }^{2}$ Department of Plant Biotechnology, Centre for Plant Molecular Biology and Biotechnology, Tamil Nadu Agricultural University, Coimbatore 641003, India. ${ }^{3}$ Department of Nano Science and Technology, Tamil Nadu Agricultural University, Coimbatore 641003, India.

Received: 23 September 2021 Accepted: 23 November 2021

Published online: 02 December 2021

\section{References}

Ben-Dov E, Zaritsky A, Dahan E, Barak ZE, Sinai R, Manasherob R, Margalith $Y$ (1997) Extended screening by PCR for seven cry group genes from field collected strains of Bacillus thuringiensis. Appl Environ Microbiol 63(12):4883-4890. https://doi.org/10.1128/aem.63.12.4883-4890.1997

Boonmee K, Thammasittirong SNR, Thammasittirong A (2019) Molecular characterization of lepidopteran specific toxin genes in Bacillus thuringiensis strains from Thailand. 3 Biotech 9:117. https://doi.org/10.1007/ s13205-019-1646-3

Bradford MM (1976) A rapid and sensitive method for the quantitation of microgram quantities of protein utilizing the principle of protein dye binding. Anal Biochem 72:248-254. https://doi.org/10.1006/abio.1976. 9999 
Carozzi NB, Kramer VC, Warren GW, Evola S, Koziel MG (1991) Prediction of insecticidal activity of Bacillus thuringiensis strains by polymerase chain reaction product profiles. Appl Environ Microbiol 57:3057-3061

Crickmore N, Baum J, Bravo A, Lereclus D, Narva K, Sampson K, Schnepf E, Sun M, Zeigler DR (2018) Bacillus thuringiensis toxin nomenclature. http:// www.btnomenclature.info/

George Z, Crickmore N (2012) Bacillus thuringiensis applications in agriculture. In: Sansinenea E (ed) Bacillus thuringiensis biotechnology, 1st edn. Springer, Dordrecht

Gupta M, Kumar H, Kaur S (2021) Vegetative insecticidal protein (Vip): potential contender from Bacillus thuringiensis for efficient management of various detrimental agricultural pests. Front Microbiol 12:659736. https://doi.org/ 10.3389/fmicb.2021.659736

Jurat-Fuentes JL, Heckel DG, Ferre J (2021) Mechanisms of resistance to insecticidal proteins from Bacillus thuringiensis. Annu Rev Entomol 66:121-140. https://doi.org/10.1146/annurev-ento-052620-073348

Kahrizeh AG, Khoramnezhad A, Hassanloui RT (2017) Isolation, characterization and toxicity of native Bacillus thuringiensis isolates from different hosts and habitats in Iran. J Plant Prot Res 57(3):212-218

Laemmli UK (1970) Cleavage of structural proteins during the assembly of the head of bacteriophage T4. Nature 227:680-685. https://doi.org/10.1038/ $227680 \mathrm{a} 0$

Logan NA, De Vos P (2011) Genus I. Bacillus. In: De Vos P, Boone DR, Garrity GM, Krieg NR, Ludwig W, Rainey FA, Schleifer KH, Whitman WB (eds) Bergey's manual of systemic bacteriology, the firmicutes, 2nd edn. Springer, Dordrecht

Lone SA, Malik A, Padaria JC (2017) Selection and characterization of Bacillus thuringiensis strains from northwestern Himalaya's toxic against Helicoverpa armigera. Microbiology Open 6(6):e00484. https://doi.org/10.1002/ mbo3.484

Monnerat RG, Batista AC, De Medeiros PT, Martins ES, Melatti VM, Praca LB, Dumas VF, Morinaga C, Demo C, Gomes ACM, Falcao R, Siqueira CB, Silva-Werneck JO, Berry C (2007) Screening of Brazilian Bacillus thuringiensis active against Spodoptera frugiperda, Plutella xylostella, Anticarsia gemmatalis. Biol Control 41:291-295. https://doi.org/10.1016/j.biocontrol. 2006.11.008

Nair K, Al-Thani R, Jaoua S, Ahmed T (2018) Diversity of Bacillus thuringiensis strains from Qatar as shown by crystal morphology, delta-endotoxins and cry gene content. Front Microbiol 9:708. https://doi.org/10.3389/fmicb. 2018.00708

Ramalakshmi A, Udayasuriyan V (2010) Diversity of Bacillus thuringiensis isolated from Western Ghats of Tamil Nadu State, India. Curr Microbiol 61:13-18. https://doi.org/10.1007/s00284-009-9569-6

Rampersad J, Ammons D (2005) A Bacillus thuringiensis isolation method utilizing a novel stain, low selection and high throughput produced atypical results. BMC Microbiol 5(1):1-11. https://doi.org/10.1186/1471-2180-5-52

Reyaz AL, Gunapriya L, Arulselvi PI (2017) Molecular characterization of indigenous Bacillus thuringiensis strains isolated from Kashmir valley. 3 Biotech 7:143-153. https://doi.org/10.1007/s13205-017-0756-z

Sahin B, Gomis-Cebolla J, Gunes H, Ferre J (2018) Characterization of Bacillus thuringiensis isolates by their insecticidal activity and their production of Cry and Vip3 proteins. PLoS ONE 13(11):e0206813. https://doi.org/10. 1371/journal.pone.0206813

Salama HS, Abd El-Ghany N, Saker M (2015) Diversity of Bacillus thuringiensis isolates from Egyptian soils as shown by molecular characterization. J Genet Eng Biotechnol 13(2):101-109. https://doi.org/10.1016/j.jgeb.2015. 10.001

Sambrook J, Russell DW (2001) Molecular cloning: a laboratory manual, 3rd edn. Cold Spring Harbor Laboratory Press, Cold Spring Harbor

Sandeep JK, Jayraj J, Shanti M, Theradimani M, Balasubramani V, Irulandi S, Prabhu S (2020) Potential of standard strains of Bacillus thuringiensis against the tomato pinworm, Tuta absoluta (Meyrick) (Lepidoptera: Gelechiidae). Egypt J Biol Pest Control 30:123. https://doi.org/10.1186/ s41938-020-00326-w

Schnepf E, Crickmore N, Van Rie J, Lereclus D, Baum J, Feitelson J, Zeigler DR, Dean DH (1998) Bacillus thuringiensis and its pesticidal crystal proteins. Microbiol Mol Biol Rev 62:775-806

Silva MC, Siqueiraa HAA, Marques EJ, Silva LM, Barros R, Lima Filho JVM, Silva SMFA (2012) Bacillus thuringiensis isolates from northeastern Brazil and their activities against Plutella xylostella (Lepidoptera: Plutellidae) and
Spodoptera frugiperda (Lepidoptera: Noctuidae). Biocontr Sci Technol 22:583-599. https://doi.org/10.1080/09583157.2012.670802

Singh D, Samiksha TSM, Sohal SK, Kesavan AK (2021) Exploration of insecticidal potential of Cry protein purified from Bacillus thuringiensis VIID1. Int J Biol Macromol 174:362-369. https://doi.org/10.1016/j.ijbiomac.2021.01.143

Swamy MHM, Asokan R, Mahmood R, Nagesha SN (2013) Molecular characterization and genetic diversity of insecticidal crystal protein genes in native Bacillus thuringiensis isolates. Curr Microbiol 66:323-330. https://doi.org/ 10.1007/s00284-012-0273-6

Zothansanga R, Kumar SN, Guru Subramanian G (2016) Diversity and toxicity of Bacillus thuringiensis from shifting cultivation (Jhum) habitat. Biocontrol Sci 21(2):99-111. https://doi.org/10.4265/bio.21.99

\section{Publisher's Note}

Springer Nature remains neutral with regard to jurisdictional claims in published maps and institutional affiliations.

\section{Submit your manuscript to a SpringerOpen ${ }^{\circ}$ journal and benefit from:}

- Convenient online submission

- Rigorous peer review

- Open access: articles freely available online

- High visibility within the field

- Retaining the copyright to your article

Submit your next manuscript at $\boldsymbol{\nabla}$ springeropen.com 